Published by LPMP Imperium

Journal homepage: https:/ / ejournal.imperiuminstitute.org/ index.php/ AKURASI

\title{
LAPORAN KEUANGAN BERBASIS STANDAR AKUNTANSI KEUANGAN ENTITAS MIKRO, KECIL DAN MENENGAH BAGI PELAKU USAHA MIKRO
}

\section{AKURASI 9}

\author{
Ati Harianti ${ }^{*}$, Ludwina Harahap ${ }^{2}$, Hendyansyah ${ }^{1}$ \\ 1Manajemen, Fakultas Ekonomi dan Bisnis, Universitas Trilogi \\ 2Akuntansi, Fakultas Ekonomi Universitas, Universitas Trilogi
}

Paper type

Accounting, Research

paper

Received: 12 Feb 2020

Revised: 07 Apr 2020

Accepted: 25 Apr 2020

Online: 30 Apr 2020 Equation Modeling, there are 2 factors that significantly influence the perceptions of SMEs in making financial reports, those are the benefits of the Financial Statements and the timing of the preparation of Financial Statements. The SME's know the benefits/advantages of preparing Financial Statements, while the challenges faced are the lack of knowledge about accounting records and the lack of suffiecient time to make financial reporting.

\begin{abstract}
Abstrak
Penelitian ini dilakukan untuk mengetahui persepsi usaha mikro dalam penyusunan laporan keuangan berbasis SAK EMKM. Dengan menggunakan data primer dan hasil small focus group discussion, serta pengujian dengan menggunakan Structural Equation Modelling, terdapat 2 faktor yang secara signifikan mempengaruhi persepsi pelaku usaha mikro dalam membuat laporan keuangan, yaitu manfaat dari Laporan Keuangan dan waktu penyusunan Laporan Keuangan. Kesimpulan dari hasil penelitian ini adalah bahwa pelaku usaha UMKM mengetahui manfaat/keuntungan dari penyusunan Laporan Keuangan, sedangkan tantangan yang dihadapi adalah minimnya pengetahuan tentang pencatatan akuntansi dan kurangnya waktu yang disediakan untuk membuat pencatatan sehingga sebagian besar pelaku usaha mikro tidak membuat pelaporan keuangan sesuai dengan SAK EMKM.
\end{abstract}

Email korespondensi: ema_harianti@trilogi.ac.id

Pedoman Sitasi: Ati Harianti, Ludwina Harahap, \& Hendyansyah. (2020). LAPORAN KEUANGAN BERBASIS STANDAR AKUNTANSI KEUANGAN ENTITAS MIKRO, KECIL DAN MENENGAH BAGI PELAKU USAHA MKRO . AKURASI: Jurnal Riset Akuntansi dan Keuangan, 2(1), 9-20. DOI: https:// doi.org/ 10.36407/ akurasi.v1i2.159
Keywords: Accounting Financial Micro Business

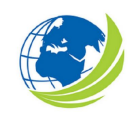

Akurasi: Jurnal Riset Akuntansi dan Keuangan, Vol 2, No.1, April 2020, pp. 9 - 20

eISSN: 2685-2888
SMES Standards, Statement, 


\section{PENDAHULUAN}

Di Indonesia berlaku 3 standar bagi dunia usaha (IAI, 2018), yaitu: SAK Umum berbasis IFRS, yang digunakan oleh entitas dengan akuntabilitas publik signifikan, SAK ETAP digunakan oleh entitas tanpa akuntabilitas publik yang signifikan namun menerbitkan laporan keuangan untuk tujuan umum bagi penggunanya; dan SAK EMKM yang digunakan oleh entitas mikro, kecil, dan menengah. SAK EMKM yang merupakan standar pelaporan keuangan bagi EMKM secara bertahap telah dilakukan simplifikasi yang bertujuan untuk mempermudah para pelaku usaha kecil dan mikro dalam menyusun laporan keuangan. Selama ini penyusunan laporan keuangan berbasis SAK EMKM dianggap masih terlalu sulit. Hal ini sesuai dengan kenyataan yang terjadi pada pelaku usaha mikro dan kecil dimana sebagian besar belum membuat laporan keuangan usaha berbasis SAK EMKM (Muyassaroh, et.al: 2015).

Pihak otoritas yaitu Ikatan Akuntan Indonesia yang secara aktif melakukan review untuk membuat simplifikasi standar pelaporan keuangan, termasuk SAK EMKM. Standar tersebut telah mengalami beberapa kali perkembangan secara bertahap (Martyniuk, Olga and Szramowski, Dawid: 2017, IAI: 2018, Ezeagba, Charles, 2017). Namun penyederhanaan standar yang telah dilakukan beberapa kali belum memberikan hasil sesuai dengan harapan (Rudiantoro, Rizki dan Siregar, Silvia Veronica, 2012; Ramona Neaga, Ema Mascaa, 2012; Maingot, Michael and Zeghal, Daniel, 2006; Martyniuk, Olga and Szramowski, Dawid, 2017; dan Hapsari, Rinci Kembang, et. al., 2016). Penyederhanaan tersebut belum memberikan pengaruh terhadap kemampuan dan kualitas laporan keuangan bagi para pelaku usaha mikro dan kecil. Mereka masih mengalami kesulitan dalam menyusun laporan keuangan yang terstandarisasi.

Penelitian Ezeagba Charles (2017) mengenai Financial Reporting in Small and Medium Enterprise (SMES) di Nigeria melihat tantangan yang dihadapi oleh SMES dalam menerapkan laporan keuangan yang effektif di Nigeria. Hasil dari penelitian tersebut ada pencatatan dan pembukuan Akuntansi , tidak memiliki Sumber Daya Manusia, tidak memiliki system Akuntansi dan tidak menggunakan Sistem Perbankan dalam melakukan transaksi. Penelitian Pramesty (2014) melakukan tinjuan dari Proprietory Theory menyebutkan bahwa manfaat karakteristik kualitatif laporan keuangan relevan bagi pelaku UMKM keramik Dinoyo sebagai: dasar pengambilan keputusan pribadi dan usaha, dimana keputusan usaha adalah untuk menerima atau menolak pesanan. Manfaat kedua adalah dapat mengetahui kondisi usahanya. Manfaat ketiga adalah Informasi keuangan seperti laba atau rugi yang diperoleh usahanya.

Studi berikutnya oleh Syafrida dan Zahra (2017) bertujuan untuk mengetahui bagaimana persepsi pelaku UMKM terhadap penyelenggaraan laporan keuangan memberikan kesimpulan bahwa pelaku UMKM menganggap bahwa laporan keuangan terlalu rumit untuk diterapkan pada usaha kecil. Selain itu, pelaku UMKM sulit menyisihkan waktu untuk mempelajari laporan keuangan karena mereka menganggap laporan keuangan tidak terlalu penting dan lebih mementingkan usaha peningkatan omzet penjualan, Penelitian Setyawati Yuli dan Hermawan Sigit (2018) tentang Persepsi pemilik dan pengetahuan akuntansi pelaku Usaha Mikro Kecil dan Menengah atas Penyusunan Laporan Keuangan. Berdasarkan penelitian tersebut kendala yang dihadapi oleh pelaku UMKM adalah (1) kurangnya pemahaman tentang Standar Akuntansi Keuangan (SAK) dan pelatihan penyusunan Laporan Keuangan. Karena pemahaman tentang akuntansi yang minim dan terbatas maka uang hasil produksi masih tercampur dengan uang kebutuhan rumah tangga. (2) Pelaku UMKM sulit untuk membat laporan keuangan karena keterbatasan waktu dan biaya.

Berdasarkan studi-studi sebelumnya terlihat bahwa pentingnya standarisasi pada laporan keuangan pada sektor usaha kecil dan menengah, namun di lapangan masih menunjukkan berbagai kesulitan yang dialami oleh pelaku UMKM untuk menerapkan standar pelaporan keuangan yang baik. Hal ini didukung oleh studi Kamaruzzaman dan Gani (2019) yang menemukan Sembilan alasan perusahaan tidak melakukan pencatatan Akuntansi, yaitu Time Consuming, Expensive, Technical skill and knowledge, More Staff, Expose Financial Position, Pay more Tax, No Need To Keep Records, Unnecessary Cost, Difficult to maintain System. Dari hasil penelitian tersebut terlihat bahwa salah satu alasan 
perusahaan tidak membuat laporan keuangan adalah menyita waktu dan biayanya mahal.

Dalam mendukung jalannya usaha, keahlian dan ilmu seperti keuangan, produksi dan lainnya sangat dibutuhkan, namun sebagian besar, pelaku usaha mikro dan kecil tidak memiliki keahlian dan kemampuan yang diperlukan tersebut. Keterbatasan tersebut menjadi kendala bagi mereka dalam melebarkan bisnisnya. Salah satu hambatan atau kesulitan dan menjadi tantangan adalah kurang pahamnya terhadap pelaporan keuangan usaha dan tentunya bagaimana membuat laporan keuangan yang sesuai dengan SAK EMKM. Kendala tersebut dapat menyebabkan pelaku usaha mikro tidak bisa memperoleh pendanaan dari bank (kredit) sebagai salah satu contohnya. Hambatan yang dihadapi oleh pelaku usaha mikro tentunya beragam. Hal inilah yang menarik peneliti untuk melakukan penelitian mengenai persepsi pelaku usaha mikro terhadap laporan keuangan. Tantangan (atau kesulitan) apa saja yang dihadapi dalam menyusun laporan keuangan yang sesuai dengan SAK EMKM

\section{KAJIAN PUSTAKA}

Standar Pelaporan Keuangan EMKM

Dewan Standar Akuntansi di Indonesia yang menyusun Standar Akuntansi Keuangan (SAK) sebagai standar bagi penyusunan laporan keuangan telah beberapa kali melakukan review dan penyempurnaan terhadap SAK yang berlaku. Salah satu tujuannya adalah agar standar pelaporan keuangan di Indonesia dapat mengadopsi standar yang berlaku internasional yaitu IFRS (International Financial Reporting Sandard). Selain itu juga agar standar tersebut dapat mengakomodir kebutuhan pengguna dan sesuai dengan kemampuan si pembuat laporan keuangan. SAK EMKM diharapkan dapat membantu EMKM mencapai literasi keuangan sehingga pelaku EMKM memiliki kemampuan mengoptimalkan setiap peluang yang ada di industri keuangan untuk memaksimalkan kinerjanya (iaiglobal, 2018).

Dewan penyusun standar pelaporan keuangan didalam menyusun standar akuntansi yang berlaku umumnya mempertimbangkan faktor-faktor sosio ekonomi, lingkungan ( Sutton, David B. et. al., 2015). Standar laporan keuangan bagi entitas mikro, kecil dan menengah yaitu SAK EMKM yang baru di launching di awal tahun 2018, telah beberapa kali mengalami evolusi atau perubahan. Diharapkan simplifikasi SAK EMKM dapat membantu sekitar 57,9 juta pelaku EMKM di Indonesia menyusun laporan keuangan tanpa harus terjebak dalam kerumitan standar akuntansi keuangan yang ada saat ini (IAI: 2018). Ikatan Akuntan Indonesia (IAI) sebagai standard setter menyiapkan Standar Akuntansi Keuangan Entitas Mikro, Kecil, Menengah dalam rangka mewujudkan EMKM Indonesia yang maju, mandiri, dan modern, serta mampu mengakses sumber pendanaan industri keuangan. Standar ini juga membantu EMKM mencapai literasi keuangan.

Laporan keuangan sebagai salah satu sumber informasi yang sangat dibutuhkan dalam pengambilan keputusan, namun kenyataannya penyusunan laporan keuangan pada uUsaha Kecil dan Menengah (UKM) masih rendah dan memiliki banyak kelemahan (Suhairi, 2004; Raharjo \& Ali, 1993; Benjamin, 1990; Muntoro, 1990 dalam Sariningtyas, Pratiwi dan Tituk Diah W.), sehingga pihak bank dan fiskus seringkali mengeluhkan ketidakmampuan atau kelemahan tersebut yang berimbas pada sulitnya akses pendanaan bank bagi pelaku UKM. Mayoritas Entitas Mikro, Kecil, dan Menengah (EMKM) di Indonesia sulit mendapatkan akses ke perbankan dan sumber pendanaan lainnya karena EMKM tidak memiliki laporan keuangan yang memadai dan sesuai standar yang berlaku di industri keuangan. Benjamin, 1990 dalam Sariningtyas, Pratiwi dan Tituk Diah W. berpendapat bahwa kelemahan UKM dalam penyusunan laporan keuangan itu antara lain disebabkan rendahnya pendidikan dan kurangnya pemahamam terhadap Standar Akuntansi Keuangan (SAK). Sedangkan Muntoro (1990) berpendapat bahwa rendahnya penyusunan laporan keuangan disebabkan karena tidak adanya peraturan yang mewajibkan penyusunan laporan keuangan bagi UKM.

\section{Pelaporan Keuangan Usaha Mikro}

Laporan keuangan adalah catatan informasi keuangan suatu perusahaan atau organisasi pada suatu periode dan bertujuan untuk menggambarkan kinerja perusahaan/organisasi tersebut. Laporan 
keuangan menyajikan informasi yang dapat digunakan atau membantu para stakeholder dalam membuat keputusan sosial, politik dan ekonomi sehingga keputusan yang diambil bisa lebih berkualitas. Beberapa studi dilakukan untuk melihat kualitas pelaporan keuangan entitas mikro dan kecil, untuk mengetahui apakah laporan keuangan bermanfaat bagi usaha kecil dan mikro (Maingot, Michael and Zeghal, Daniel, 2006), atau apakah standar akuntansi untuk pelaporan keuangan usaha kecil dan mikro perlu dilakukan simplifikasi atau penyederhanaan (Martyniuk, Olga and Szramowski, Dawid, 2017; Hapsari, Rinci Kembang, et. al., 2016; Ramona Neaga, Ema Mascaa, 2012; Ezeagba, Charles, 2017).

Usaha kecil dan mikro mendominasi para pelaku usaha di Indonesia dan bahkan memberikan sumbangan yang sangat besar bagi PDB Indonesia. Ketika krisis ekonomi melanda Indonesia dan dunia global lainnya, usaha mikro di Indonesia terbukti mampu bertahan. Besarnya sumbangsih dari usaha mikro tidak sebanding dengan perhatian yang diberikan pemerintah dalam memajukan ekonomi melalui pelaku usaha mikro. Mengapa pelaku usaha mikro sangat sulit untuk mengembangkan dan melebarkan sayapnya? Selain dari kurang perhatian dan uluran tangan dari pihak pemerintah, penyebab utama adalah faktor internal pelaku usaha. Usaha mikro di Indonesia kurang bisa berkembang dibandingkan di Negara lain, seperti di Eropa, dimana pemerintah sangat memberikan dukungan dan bantuan bagi perkembangan usaha mikro, yaitu berupa standar akuntansi bagi usaha mikro, yang dibuat secara sederhana dan memudahkan penyusunannya (Ramona Neaga, Ema Mascaa, 2012).

Hampir sebagian besar EMKM adalah para pelaku usaha kecil yang memiliki prospek usaha namun tidak memiliki akses yang baik kepada sumber pendanaan, khususnya perbankan dengan alasan EMKM ini tidak memiliki laporan keuangan yang dapat diterima sebagai dasar bagi perbankan atau lembaga keuangan lainnya untuk bisa memberikan pinjaman dana. SAK ETAP maupun SAK EMKM disusun berdasarkan kondisi domestik Indonesia, sederhana, dan diperuntukkan entitas yang tidak memiliki akuntabilitas publik yang signifikan. SAK EMKM memiliki beberapa kekhususan, beberapa diantaranya adalah komponen laporan keuangan EMKM hanya terdiri dari neraca, laporan laba rugi dan catatan atas laporan keuangan, dasar pengukuran unsur-unsur laporan keuangan hanya dengan basis biaya historis, dan kemudahan lainnya. Dengan penerbitan SAK EMKM oleh DSAK ini, maka disamping diharapkan dapat memberikan kemudahan kepada pelaku usaha EMKM dalam menyusun laporan keuangan sehingga nantinya dapat menjadi dasar pengambilan keputusan oleh manajemen EMKM dan pihak lain (perbankan, lembaga keuangan, dan lain-lain), SAK ini juga diharapkan dapat menjadi jembatan bagi entitas EMKMyang terbiasa menggunakan basis kas menjadi akrual (IAI, 2018).

Usaha mikro adalah usaha ekonomi produktif yang berdiri sendiri, yang dilakukan oleh perorangan atau badan usaha yang bukan merupakan anak perusahaan atau bukan cabang perusahaan yang dimiliki, dikuasai, atau menjadi bagian baik langsung maupun tidak langsung dari usaha menengah atau usaha besar, memiliki kekayaan bersih paling banyak Rp 50.000.000,00 - lima puluh juta rupiah, tidak termasuk tanah dan bangunan tempat usaha; atau memiliki hasil penjualan tahunan paling banyak Rp 300.000.000,00 - tiga ratus juta rupiah. Di Eropa laporan keuangan digunakan oleh usaha kecil, mikro dan entitas mikro sebagai sumber informasi keuangan dan akan semakin berkembangnya usaha kebutuhan sumber informasi keuangan dan pelaporan keuangan meningkat (Ramona Neaga, Ema Mascaa. 2012). Sayangnya di Indonesia, kebutuhan akan laporan keuangan dikesampingkan mengingat kesulitan dan ketidakmampuan pelaku usaha mikro menyusun laporan keuangan (Muyassaroh, Opti, Sri dan Harahap, Ludwina, 2014).

Pencatatan akuntansi mempunyai peran yang penting bagi pelaku usaha mikro, kecil dan menengah dalam mencapai keberhasilan usahanya. Laporan keuangan sebagai produk akhir dari siklus akuntansi menjadi dasar bagi pengambilang keputusan dalam pengelolaan usaha. Pengembangan pasar, penetapan harga, menilai kinerja usaha, dan lain-lain lebih mudah dan akurat dalam pengambilan keputusan apabila didasarkan pada informasi keuangan atau laporan keuangan usaha. Atau untuk mengetahui apakah suatu usaha memperoleh keuntungan/laba dapat dilihat dari catatan yang 
dinamakan laporan laba rugi.

Beberapa hasil penelitian menunjukkan bahwa sebagai besar pelaku usaha mikro dan kecil tidak membuat laporan keuangan (Muyassaroh, et.al: 2016). Sebagian dari mereka hanya memiliki catatan penerimaan dan pengeluaran kas. Bahkan pencatatan tersebut dilakukan tidak secara rutin dan menggunakan selembar kertas seadaanya. Beberapa penyebab tidak dibuatnya laporan keuangan berbasis SAK EMKM adalah:

1. Kurang pentingnya/ digunakan informasi akuntansi yang terkandung dalam laporan keuangan bagi EMKM

2. Kurangnya pengetahuan akuntansi pelaku usaha EMKM

3. Pertimbangan biaya dan manfaat (cost benefit effectiveness) bagi EMKM

\section{METODE PENELITIAN}

Desain Penelitian

Penelitian yang dilakukan merupakan penelitian deskriptif kuantitatif dimana penelitian yang akan dilakukan mempunyai tujuan untuk menjelaskan fenomena yang ada dengan menggunakan angkaangka berdasarkan karakteristik individu atau kelompok yang diteliti (Sugiono; 2014). Penelitian dengan metode deskriptif memungkinkan peneliti melakukan hubungan antar variabel, menguji hipotesis, dan mengembangkan generalisasi atau penelitian dimana pengumpulan data untuk mengetes pertanyaan penelitian atau hipotesis yang berkaitan dengan keadan dan kejadian sekarang (Sugiyono, 2012).

Populasi dan Sampel

Data yang digunakan adalah data primer. Pemilihan sampel yang digunakan dalam penelitian ini adalah purposive sampling yang diperoleh dari hasil kuesioner kepada 300 pelaku UMKM yang berada di Jakarta Selatan. Item pernyataan yang dibentuk dalam susunan kuesioner mengadopsi penelitian Ezeagba (2017).

Pengukuran Variabel

Metode pengumpulan data yang digunakan dalam penelitian ini adalah metode kuesioner. Kuesioner adalah sejumlah pertanyaan tertulis yang digunakan untuk memperoleh informasi dari responden tentang hal-hal yang diketahuinya (Arikunto,2006). Survey pengumpulan data primer diperoleh dengan cara membagikan sejumlah kuesioner kepada para responden dan kemudian responden akan mengisinya sesuai dengan pendapat dan persepsi responden. Kuesioner dalam penelitian ini disusun menggunakan skala Likert. Penelitian ini akan menggunakan skala Likert 1 - 4 dengan rincian sebagai berkut : 1 =Sangat Tidak Setuju, 2 =Tidak Setuju, 3 =Setuju, 4 = Sangat Setuju.

Teknik Analisis

Setelah data diperoleh dari hasil kuesioner kemudian diolah dengan teknik Simultaneous Equation Modelling (SEM) dan dengan bantuan Aplikasi Smart PLS 3 dan tahap selanjutnya hasilnya akan dianalisis secara deskriptif dan terakhir untuk ditarik kesimpulan. Penelitian ini bukan ditujukan untuk melakukan generalisasi suatu populasi, mengingat keterbatasan penelitian yaitu kesulitan untuk memperoleh sampel penelitian. Kesulitan tersebut berhubungan dengan keterbatasan waktu dan dana yang dimiliki oleh peneliti sehingga penyebaran kuesioner dilakukan secara random.

\section{HASIL DAN PEMBAHASAN}

Analisis deskriptif

Berdasarkan hasil penyebaran kuesioner pada responden di lapangan diperoleh data-data mengenai karakteristik responden. Pada penelitian ini peneliti mengelompokkan responden ke dalam beberapa karakteristik. Berikut Karakteristik dari responden yang merupakan usaha EMKM yang berada di 
daerah Jakarta Selatan. Data-data mengenai karakteristik responden disajikan dalam tabel 1 dibawah ini. Berdasarkan data yang diolah dari hasil kuesioner, responden yang paling banyak adalah responden perempuan sebesar 50,7\% dan 49,3\% adalah laki-laki. Persentase terbesar responden berusia antara 20-29 tahun sebanyak responden $41 \%$. Berdasarkan jenjang pendidikan sebagian besar responden $64 \%$ menempuh jenjang pendidikan SMA. Sebagian besar responden (60\%) memiliki usaha kurang dari 5 tahun. Jenis usaha responden sebanyak 55\% berusaha dibidang kuliner dan 81,7 \% usaha EMKM berjualan di Ruko dan sisanya merupakan PKL. Sebanyak 65,33\% responden pernah mendapatkan sosialisasi mengenai SAK ETAP atau mengenai Laporan Keuangan. Status responden yang mengisi kuesioner sebagain besar (52\%) pemilik EMKM.ote: hasil penelitian menjawab hipotesis yang diajukan berdasarkan teknik analisis yang sudah dijelaskan. Hasil penelitian dilanjutkan dengan pembahasan yang memadai.

Tabel 1. Karakteristik Responden

\begin{tabular}{|c|c|c|c|}
\hline \multicolumn{2}{|c|}{ Variabels } & $\mathrm{N}$ & $\%$ \\
\hline \multirow{2}{*}{ Jenis Kelamin } & Laki-Laki & 148 & 49.3 \\
\hline & Perempuan & 152 & 50.7 \\
\hline \multirow{6}{*}{ Usia Responden } & $<20$ & 15 & 5.0 \\
\hline & $20-29$ & 123 & 41.0 \\
\hline & $30-39$ & 75 & 25.0 \\
\hline & $40-49$ & 68 & 22.7 \\
\hline & $50-59$ & 14 & 4.7 \\
\hline & $>60$ & 5 & 1.7 \\
\hline \multirow{5}{*}{ Pendidikan Responden } & SD & 12 & 4 \\
\hline & SMP & 36 & 12 \\
\hline & SMA/ SMK & 192 & 64 \\
\hline & D1,D3 & 7 & 2,3 \\
\hline & S1 & 53 & 17,7 \\
\hline \multirow{5}{*}{ Lama Usaha } & $<5$ & 180 & 60.0 \\
\hline & $6-10$ & 70 & 23.3 \\
\hline & $11-15$ & 21 & 7.0 \\
\hline & $16-20$ & 22 & 7.3 \\
\hline & $>20$ & 7 & 2.3 \\
\hline \multirow{5}{*}{ Jenis Usaha } & Makanan & 166 & 55.3 \\
\hline & Fashion & 34 & 11.3 \\
\hline & Elektronik & 4 & 1.3 \\
\hline & Kelontong & 10 & 3.3 \\
\hline & Lain-lain & 86 & 28.7 \\
\hline \multirow{2}{*}{ Tempat usaha } & Ruko & 245 & 81.7 \\
\hline & PKL & 55 & 18.3 \\
\hline \multirow{2}{*}{$\begin{array}{l}\text { Sosialisasi SAK ETAP/ Laporan } \\
\text { Keuangan }\end{array}$} & Pernah & 196 & 65.33 \\
\hline & Tidak pernah & 104 & 34.67 \\
\hline \multirow{4}{*}{ Status Responden } & Pemilik & 156 & 52.00 \\
\hline & Karyawan & 134 & 44.67 \\
\hline & Mamajer/ Orang & & \\
\hline & Kepercayaan & 10 & 3.33 \\
\hline
\end{tabular}

Sumber : diolah

Evaluasi Hasil Pengukuran (Outer Model)

Dalam penelitian ini peneliti menggunakan Partial Least Square (PLS) untuk mengukur hubungan setiap 
Ati Harianti, Ludwina Harahap, \& Hendyansyah, Standar akuntansi laporan keuangan UMKM....

indikator dengan konstruknya. Analisis data dilakukan dengan memasukkan data responden dan menguji Convergent validity dan Discriminant validity. Evaluasi model pengukur adalah evalusi hubungan antara konstruk dengan indikatornya. Model pengukuran atau outer model meliputu dua tahap, yaitu evaluasi terhadap Convergent Validity (besarnya loading factor untuk masing masing konstruk). Convergent validity dari model pengukuran refleksif indikator dinilai berdasarkan korelasi antara item score dengan construct score yang dihitung dengan PLS. Ukuran refleksif individual dikatakan tinggi jika berkorelasi lebih dari 0,70 dengan konstruk yang diukur.

\section{Evaluasi Convergent Validity}

Dengan Menggunakan smart PLS 3 dilakukan pengukuran terhadap indikator Sumber Daya Manusia, Waktu untuk menyusun Laporan Keuangan, dan Manfaat laporan Keuangan sebagai variable X1, X2 dan X3 dan Penyusunan laporan keuangan sebagai variable Y. Loading factor adalah besar korelasi antara indikator dengan konstruk latennya. Pengukuran suatu konstruk sangat sering dilakukan secara tidak langsung melalui indikator-indikatornya. Indikator dengan loading factor yang tinggi memiliki kontribusi yang tinggi untuk menjelaskan konstruk latennya. Sebaliknya pada indikator dengan loading factor rendah memiliki konstribusi yang lemah untuk menjelaskan konstruk latennya. Indikator validitas dapat dilihat dari loading factor. Bila nilai loading factor suatu indikator lebih besar dari 0,70, maka indicator tersebut dapat dikatakan valid. Sedangkan bila nilai loading factor lebih kecil dari 0,70 maka indicator tersebut dikeluarkan dari model. Berdasrkan hasil PLS Alogarithm di atas maka ada beberapa indikator reflektif akan dikeluarkan dari model karena memiliki loading factor lebih kecil dari 0,70. Setelah indikator dikeluarkan maka diperoleh hasil sebagai berikut.

Evaluasi selanjutnya dari Convergent Validity adalah Reliabilitas Konstruk dengan melihat Cronbach's alpha dan Composite Reliability. Bila nilai Composite Reliability lebih besar dari 0,70 dan Cronbach's Alpha di atas 0,60 maka konstruk dinyatakan reliabel. Tabel 3 menunjukan Nilai Cronbach's Alpha memiliki nilai diatas 0,60 dan Composite Reliabilitas diatas 0,70 untuk semua konstruk. Maka dapat dikatakan bahwa variabel Sumber Daya Manusia, Waktu Menyusun Laporan Keuangan, Manfaat Laporan Keuangan, dan Penyusunan Laporan Keuangan, memiliki validitas dan reliabilitas yang baik. Evaluasi terakhir dari Convergent Validity adalah melihat nilai Average Variance Extracted (AVE). Berdasarkan Tabel 2 semua nilai AVE konstruk lebih besar dari 0,50, maka dapat disimpulkan semua konstruk memiliki Convergent Validity yang baik.

Tabel 2 Nilai Loading Factor

\begin{tabular}{|l|cc|}
\hline & Indikator & Loading Factor \\
\hline \multirow{2}{*}{ Sumber Daya Manusia } & PSDM2 & 0.925 \\
& PSDM3 & 0.912 \\
\hline Waktu Menyusun LK & PWKT3 & 1000 \\
\hline \multirow{5}{*}{ Manfaat LK } & PMFT3 & 0.781 \\
& PMFT4 & 0.901 \\
& PMFT5 & 0.839 \\
& PMFT6 & 0.897 \\
\hline \multirow{3}{*}{ Penyusunan LK } & PPLK10 & 0.871 \\
& PPLK11 & 0.874 \\
& PPLK6 & 0.857 \\
& PPLK7 & 0.863 \\
& PPLK8 & 0.746 \\
\hline
\end{tabular}

Sumber : Data Primer Diolah 
Tabel 3. Nilai Composite Reliability, Cronbach's Alpha dan AVE

\begin{tabular}{lccr}
\hline & $\begin{array}{c}\text { Cronbach's } \\
\text { Alpha }\end{array}$ & $\begin{array}{c}\text { Average Variance } \\
\text { Extracted (AVE) }\end{array}$ \\
\hline Manfaat LK & 0.877 & 0.916 & 0.732 \\
Penyusunan LK & 0.898 & 0.925 & 0.712 \\
Sumber Daya Manusia & 0.815 & 0.915 & 0.844 \\
Waktu Menyusun LK & 1.000 & 1.000 & 1.000 \\
\hline
\end{tabular}

Sumber : Data Primer Diolah

Evaluasi Discriminant Validity

Evaluasi Discriminat validity dilakukan dalam 2 tahap, yaitu melihat nilai cross loadings dan FornellLarcker Criterium antara indicator dan konstruknya. Discriminat validity setiap variable dalam mengukur variable laten ditunjukkan oleh Cross Loading. Suatu variabel dikatakan memiliki Discriminant Validity apabila Cross Loading suatu indikator pada suatu variabel lebih besar dari variable lainnya. Hasil nilai Cross Loading dari tabel dibawah ini terlihat bahwa korelasi konstruk dengan masing masing indikatornya lebih tinggi dibandingkan korelasi dengan indikator lainnya. Hasil Cross Loading pada tabel 4.9 dibawah terlihat bahwa Korelasi Manfaat Laporan Keuangan, dengan indikatornya PMFT 3, PMFT 4, PMFT 5 dan PMFT 6 lebih tinggi dibandingkan indikator lain. Hal ini juga terlihat pada konstruk Sumber Daya Manusia, Waktu Menyusun Laporan Keuangan, dan Penyusunan Laporan Keuangan.

Hasil nilai Cross Loading dari tabel 4 terlihat bahwa korelasi konstruk dengan masing masing indikatornya lebih tinggi dibandingkan korelasi dengan indicator lainnya. Hasil Cross Loading pada tabel 5 dibawah terlihat bahwa Korelasi Manfaat LK dengan indikatornya PMFT 3, PMFT 4, PMFT 5 dan PMFT 6 lebih tinggi dibandingkan indicator lain. Hal ini juga terlihat pada konstruk Sumber Daya Manusia, Waktu Menyusun Laporan Keuangan, dan Penyusunan Laporan Keuangan. Discriminant Validity melalui Fornell-Larcker Criterium diuji dengan membandingkan nilai akar kuadrat AVE dengan nilai korelasi antar konstruk.

Tabel 4. Nilai Cross Loading

\begin{tabular}{|l|c|c|c|c|}
\hline & Manfaat LK & $\begin{array}{c}\text { Penyusunan } \\
\text { LK }\end{array}$ & $\begin{array}{c}\text { Sumber Daya } \\
\text { Manusia }\end{array}$ & $\begin{array}{c}\text { Waktu } \\
\text { Menyusun } \\
\text { LK }\end{array}$ \\
\hline PMFT3 & 0.781 & 0.62 & 0.299 & -0.356 \\
\hline PMFT4 & 0.901 & 0.75 & 0.428 & -0.512 \\
\hline PMFT5 & 0.839 & 0.78 & 0.623 & -0.713 \\
\hline PMFT6 & 0.897 & 0.789 & 0.514 & -0.685 \\
\hline PPLK10 & 0.725 & 0.871 & 0.329 & -0.648 \\
\hline PPLK11 & 0.738 & 0.874 & 0.311 & -0.627 \\
\hline PPLK6 & 0.781 & 0.857 & 0.456 & -0.584 \\
\hline PPLK7 & 0.793 & 0.863 & 0.537 & -0.563 \\
\hline PPLK8 & 0.591 & 0.746 & 0.552 & -0.639 \\
\hline PSDM2 & 0.522 & 0.489 & 0.925 & -0.46 \\
\hline PSDM3 & 0.496 & 0.454 & 0.912 & -0.471 \\
\hline PWKT3 & -0.675 & -0.722 & -0.507 & 1 \\
\hline
\end{tabular}

Sumber : Data Primer Diolah 
AKURASI, 2(1), 9 - 20

Ati Harianti, Ludwina Harahap, \& Hendyansyah, Standar akuntansi laporan keuangan UMKM....

Berdasarkan Tabel 5 dapat dilihat bahwa Manfaat LK memiliki nilai yang paling tinggi $(0,856)$ dibandingkan korelasi dengan konstruk Penyusunan LK $(0,834)$, Sumber Daya Manusia $(0,555)$ dan Waktu Menyusun Laporan Keuangan, $(-0,675)$. Hasil ini juga terbukti pada variabel yang lain, sehingga semua variabel dikatakan memenuhi syarat.

Tabel 5. Discriminant Validity

\begin{tabular}{|l|r|r|r|r|}
\hline & Manfaat LK & $\begin{array}{c}\text { Penyusunan } \\
\text { LK }\end{array}$ & $\begin{array}{c}\text { Sumber Daya } \\
\text { Manusia }\end{array}$ & $\begin{array}{c}\text { Waktu } \\
\text { Menyusun LK }\end{array}$ \\
\hline Manfaat LK & $\mathbf{0 . 8 5 6}$ & & & \\
\hline Membuat LK & 0.834 & $\mathbf{0 . 8 4 4}$ & & \\
\hline Sumber Daya Manussia & 0.555 & 0.514 & $\mathbf{0 . 9 1 9}$ & \\
\hline Waktu membuat LK & -0.675 & -0.722 & -0.507 & $\mathbf{1 . 0 0 0}$ \\
\hline
\end{tabular}

Sumber : Data Primer diolah

Evaluasi Inner Model (Model Struktural)

Setelah pemeriksaan model uji untuk outer model terpenuhi, maka selanjutnya adalah melakukan uji untuk mengetahui nilai dari inner model atau struktural untuk melihat hubungan antar variabel laten. Berikut adalah hasil Bootstrapping. Dalam menilai model dengan PLS dimulai dengan melihat R-square. Nilai R-square yang diperoleh adalah 0,782 artinya variabel Sumber Daya Manusia, Waktu Menyusun Laporan Keuangan dan Manfaat Laporan Keuangan dapat menjelaskan variabel Penyusunan Laporan keuangan sebesar $78,2 \%$

Pengujian Hipotesa dan Pembahasan

Signifikansi parameter yang diestimasi memberikan informasi yang sangat berguna mengenai hubungan antara variabel-variabel penelitian. Dasar yang digunakan dalam menguji hipotesis adalah nilai yang terdapat pada outer path coefficient. Dalam hal ini dilakukan metode bootstrap terhadap sampel.

Tabel 6 Path Coefficient

\begin{tabular}{|l|c|c|c|c|c|}
\hline & $\begin{array}{c}\text { Original } \\
\text { Sample } \\
(\mathrm{O})\end{array}$ & $\begin{array}{c}\text { Sample } \\
\text { Mean } \\
(\mathrm{M})\end{array}$ & $\begin{array}{c}\text { Standard } \\
\text { Deviation } \\
(\text { STDEV })\end{array}$ & $\begin{array}{c}\text { T Statistics } \\
(\mid \mathrm{O} / \text { STDEV|) }\end{array}$ & $\begin{array}{c}\mathrm{P} \\
\text { Values }\end{array}$ \\
\hline Manfaat LK ->Membuat LK & 0.69 & 0.691 & 0.037 & 18.594 & 0 \\
\hline $\begin{array}{l}\text { Sumber Daya Manussia -> Membuat } \\
\text { LK }\end{array}$ & 0.001 & 0.003 & 0.046 & 0.032 & 0.974 \\
\hline Waktu membuat LK -> Membuat LK & -0.256 & -0.255 & 0.048 & 5.267 & 0 \\
\hline
\end{tabular}

Sumber : Data Primer Diolah

Hipotesis pertama, berdasarkan t statistic pada tabel 6 menunjukkan bahwa nilai t statistic berada diatas 1,96 yaitu sebesar 18.594 dan nilai original sampel estimate adalah positif sebesar 0,69 yang menunjukkan bahwa terdapat pengaruh positif antara Manfaat Laporan Keuangan terhadap Pembuatan laporan Keuangan. Dengan demikian H1 dalam penelitian ini yang menyatakan bahwa Manfaat Laporan Keuangan berpengaruh terhadap pembuatan laporan keuangan diterima. Hal ini sesuai dengan penelitian yang dilakukan oleh Pramesty yang berkesimpulan bahwa ada 3 manfaat Laporan Keuangan bagi usaha UMKM. Yang pertama adalah sebagai dasar pengambilan keputusan pribadi dan usaha, dimana kebutuhan usaha yang dimaksud adalah keputusan untuk menerima atau menolak pesanan. Manfaat ke dua dari laporan keuangan dapat mengetahui kondisi usaha. Manfaat ke tiga yaitu informasi keuangan dapat segera dipahami artinya Laba atau Rugi usaha segera diketahui.

Pengujian Hipotesa 2, menunjukkan bahwa nilai t statistic berada dibawah 1,96 yaitu sebesar 
0,032 dan nilai original sampel estimate adalah positif sebesar 0,001 yang menunjukkan bahwa terdapat pengaruh positif antara Sumber Daya Manusia terhadap Pembuatan Laporan Keuangan. Dengan demikian H2 dalam penelitian ini yang menyatakan bahwa Sumber Daya Manusia berpengaruh terhadap pebuatan laporan keuangan ditolak. Pada umumnya usaha kecil dan menengah tidak bias membayar tenaga ahli untuk menyelesaikan pekerjaan tertentu. Terutama untuk menusun laporan keuangan karena umumnya usaha skala kecil memiliki anggaran yang terbatas.

Pengujian Hipotesa 3, menunjukkan bahwa nilai t statistic berada diatas 1,96 yaitu sebesar 5,267 dan nilai original sampel estimate adalah negative 0,256 yang menunjukkan bahwa terdapat pengaruh negative antara waktu untuk menyusun Laporan Keuangan terhadap Penyusunan Laporan Keuangan. Dengan demikian H3 dalam penelitian ini yang menyatakan bahwa Waktu penyusunan Laporan Keuangan berpengaruh terhadap penyusunan Laporan Keuangan diterima. Hal ini sesuai dengan penelitian dari Setyawati Yuli dan Hermawan Sigit yang mengatakan bahwa pemilik usaha tidak memiliki dasar-dasar keilmuan yang dibutuhkan sehingga menganggap melakukan pencatatan keuangan itu pekerjaan sulit dan rumit sehingga menghabiskan banyak waktu jika dilakukan Dari kuesioner yang sudah diolah terlihat bahwa sebagian besar responden yang menjawab kuesioner adalah pemilik usaha UMKM. Pemilik usaha khususnya usaha mikro, kecil dan menengah tidak memprioritaskan pencatatan keuangan sebagai aktivitas utama karena banyaknya hal yang harus dikerjakan oleh pemilik, seperti melakukan promosi, meningkatkan kualitas produk, memperbanyak kuantitas produk, dan lain sebagainya.

\section{KESIMPULAN}

Dari hasil pembahasan dapat ditarik kesimpulan, yaitu dari hasil penelitian adalah bahwa manfaat Laporan Keuangan berpengaruh terhadap pembuatan laporan keuangan pelaku usaha UMKM, dan waktu yang digunakan untuk menyusunan Laporan Keuangan berpengaruh terhadap penyusunan Laporan Keuangan. Hal ini membuktikan bahwa dengan mengetahui manfaat pelaporan keuangan bagi usahanya maka aka nada keinginan dari pelaku usaha mikro untuk memiliki laporan keuangan. Salah satu manfaat memiliki laporan keuangan yaitu pelaku usaha mengetahui kinerja atau performa dari usaha atau bisnis yang dijalanani. Dengan mengetahui kinerja usaha akan membantu dalam pengambilan keputusan. Faktor lainnya yaitu waktu yang tersedia untuk membuat laporan keuangan mempengaruhi pelaku usaha dalam menyusun laporan keuangan. Sebagian besar pelaku usaha mikro lebih memilih menggunakan sebagian besar waktunya untuk mengurus usaha seperti memproduksi, mengembangkan produk, dan lain-lain dibandingkan waktu yang tersedia untuk menyusun laporan keuangan.

Implikasi Praktis / Teoritis

Implikasi dari hasil ini berupa harus adanya dorongan dari pihak yang memiliki otoritas untuk melakukan sosialisasi, pelatihan dan pemahaman kepada pelaku usaha mikro tentang kebermanfaatan memiliki pelaporan keuagan, terlebih yang sesuai dengan standar akuntansi EMKM. Bagi pelaku usaha, harus diberikan kesadaran bahwa selain mengurus operasional usaha, melakukan pencatatan pun juga harus dilakukan.

Keterbasan dan Saran

Keterbatasan dalam penelitian ini adalah kesulitan dalam memperoleh responden, terutama pelaku usaha selain pedagang kaki lima, seperti usaha yang berada di pusat pertokoan atau mall.

\section{REFERENSI}

W Asdep Bidang Industri, UKM, Perdagangan, dan Ketenagakerjaan). Perizinan Usaha Mikro Dan Kecil Didelegasikan Ke Daerah. Retreived from http:// setkab.go.id/ perizinan-usaha-mikro-dan-kecil- 
didelegasikan-ke-daerah).

Ezeagba, C. (2017). Architecture Application Model View Controller (MVC) in Designing Information System of MSME Financial Report April 2017. https://www.researchgate.net. publication/ 321995077 diakses 15 Mei 2018.

Ezeagba, C. (2017). Financial Reporting in Small and Medium Enterprises (SMEs) in Nigeria, Challenges and Options. International Journal of Academic Research in Accounting, Finance and Management Sciences, 7(1), 1-10.

Fitriana, N. D. (2014). Buku Praktis Menyusun Laporan Laba Rugi.Jakarta : Laskar Aksara.

Hani, S. (2019). Persepsi Pelaku UKM Terhadap Penyelenggaraan Laporan Keuangan.

Hapsari, R. K et. al. (2016). Analysis and Design of Information Systems Financial Reports with Object Oriented Approach. International Journal of Computational Engineering Research (IJCER). 6(11), .

Heri. (2014). Cara Mudah Membuat Pembukuan Sederhana. Jakarta. Grasindo.

http:// iaiglobal.or.id/v03/ berita-kegiatan/ detailberita-917=press-release--iaisiapkanstandarakuntansi-agar-emkm-capai-literasi-keuangan)

Ikatan Akuntan Indonesia. (2009). PSAK No 1 Revisi 2009 Laporan Keuangan. Jakarta: Ikatan Akuntan Indonesia.

Ikatan Akuntan Indonesia. (2009). PSAK No 2 Revisi 2009 Laporan Arus Kas. Jakarta: Ikatan Akuntan Indonesia.

Ikatan Akuntan Indonesia. (2011). PSAK No 45 Revisi 2011 Pelaporan Keuangan Entitas Nirlaba. Jakarta: Ikatan Akuntan Indonesia.

Muhammad, K., \& Ghani, E. K. (2019). Assessing Financial Reporting Practices of Small Retailers: A Malaysian Evidence. The Journal of Social Sciences Research, 140-149.

Maingot, Michael and Zeghal, Daniel. Financial Reporting of Small Business Entities in Canada. Journal of Small Business Management. 2006.44 (4). 513-530.

Martyniuk, Olga and Szramowski, Dawid. 2017. Financial Reporting for Micro Entities - A Case of Selected Eastern European Country. Retrieve from https:// www.researchgate.net.publication/32471986.

Muyassaroh, et. al. (2014). Pemahaman Pelaku Usaha Mikro Terhadap Laporan Keuangan. Hasil penelitian yang tidak dipublikasikan.

Neag, R., \& Maşca, E. (2012). Determinants in accounting regulation for Micro-Entities-a Romanian perspective. Procedia Economics and Finance, 3, 223-229.

Pramesty, I.A. (2014). Manfaat Laporan Keuangan Bagi Pelaku Usaha Mikro dan Menengah (UMKM) Keramik Dinoyo (Tinjauan Berdasrkan Propietory Theory), Skripsi, Program S-1 Jursan Akuntansi Fakultas Ekonomi Universitas Negeri Malang.

Rudiantoro, R., \& Siregar, S. V. (2012). Kualitas laporan keuangan umkm serta prospek implementasi SAK ETAP. Jurnal Akuntansi dan Keuangan Indonesia, 9(1), 1-21.

Sariningtyas, P., \& Diah, T. (2011). Standar akuntansi keuangan entitas tanpa akuntabilitas publik pada Usaha Kecil Dan Menengah. Jurnal Akuntansi dan Keuangan Indonesia, 1(1), 90-101.

Setiyawati, Y., \& Hermawan, S. (2018). Persepsi Pemilik Dan Pengetahuan Akuntansi Pelaku Usaha Mikro Kecil Dan Menengah (UMKM) Atas Penyusunan Laporan Keuangan. Riset Akuntansi dan Keuangan Indonesia, 3(2), 161-204.

www.bi.go.id. 2009. Standar Akuntansi Keuangan Entitas Tanpa Akuntabilitas Publik. Retrieved from http:// www.iaiglobal.or.id/ 


\section{PROFIL PENULIS}

Ati Harianti adalah dosen Prodi Manajemen Fakultas Ekonomi Universitas Trilogi, dengan pengalaman mengajar program sarjana di bidang Manajemen Keuangan, Manajemen Resiko dan beberapa matakuliah kuantitatif lainnya. Penulis memiliki ketertarikan pada penelitian manajemen keuangan, portofolio.Email yang dapat dihubungi di: a_harianti@trilogi.ac.id

Ludwina Harahap adalah dosen Prodi Akuntansi Fakultas Ekonomi Universitas Trilogi, dengan pengalaman mengajar program sarjana di bidang Akuntansi Manajemen, Pengendalian Manajemen, Akuntansi Keuangan, dan beberapa matakuliah akuntansi perilaku lainnya. Penulis memiliki ketertarikan pada penelitian akuntansi manajemen dan perilaku. Email yang dapat dihubungi di: ludyhara@trilogi.ac.id

Hendyansyah Putera adalah dosen Prodi Manajemen Fakultas Ekonomi Universitas Trilogi, dengan pengalaman mengajar program sarjana di bidang Manajemen Pemasaran, Kewirausahaan, Teknoprener, dan beberapa matakuliah manajemen lainnya. Penulis memiliki ketertarikan pada penelitian manajemen secara umum. Email yang dapat dihubungi di: hendyansyah@trilogi.ac.id

Akurasi: Jurnal Riset Akuntansi dan Keuangan, Vol 2, No.1, April 2020, pp. 9-20 eISSN: 2685-2888

Journal homepage: https:/ / ejournal.imperiuminstitute.org/index.php/ AKURASI 